DE

M E D I C I N A

T R O P I C A L

$\mathrm{DE}$

SÃO PAULO

JOURNAL OF THE SÃO PAULO INSTITUTE OF TROPICAL MEDICINE

'Secretaria de Estado da Saúde, Coordenadoria de Controle de Doenças, Centro de Vigilância Epidemiológica "Prof. Alexandre Vranjac", Divisão de Imunização, São Paulo, São Paulo, Brazil

${ }^{2}$ Instituto Adolfo Lutz, Núcleo de Doenças de Transmissão Vetorial, São Paulo, São Paulo, Brazil

Correspondence to: Eder Gatti Fernandes Secretaria de Estado da Saúde de São Paulo, Coordenadoria de Controle de Doenças, Centro de Vigilância Epidemiológica "Prof. Alexandre Vranjac", Divisão de Imunização, Av. Dr Arnaldo, 351, $6^{\circ}$ andar, Pacaembu, CEP 01246-000, São Paulo, SP, Brazil

Tel: $+55113066-8779$

E-mail: edergatti@ hotmail.com

Received: 22 January 2020

Accepted: 22 April 2020

\section{The search for yellow fever virus vaccine in breast milk of inadvertently vaccinated women in Brazil}

\author{
Eder Gatti Fernandes ${ }^{(1)}$, Juliana Silva Nogueira ${ }^{\left({ }^{2}\right.}$, Victor Bertollo Gomes \\ Porto ${ }^{1}$, Helena Keico Sato ${ }^{1} 1$
}

\section{ABSTRACT}

Eleven lactating women were inadvertently vaccinated with 17DD yellow fever vaccine in a small city of Sao Paulo State, Brazil. Their infants were being exclusively breast-fed and the breastfeeding was interrupted for 10 days. Serum and breastmilk were collected from the vaccinated mothers and tested for the presence of genomic RNA of the vaccine strain 8, 10 and 15 days after vaccination. Viral RNA was not detected in any of the serum and human milk samples tested and the infants remained asymptomatic. Our result strengthens the effectineness of stopping breastfeeding for 10 days after the inadvertent yellow fever vaccination of lactating women.

KEYWORDS: Yellow fever vaccine. Breast feeding. Adverse events. Brazil.

\section{INTRODUCTION}

On April 17 2017, 11 women had scheduled measles, mumps, and rubella (MMR) vaccination in the first postpartum visit in a primary health care unit in Angatuba, a small city with approximately 24,000 inhabitants in Sao Paulo State, Brazil. However, the 11 women were inadvertently vaccinated with the 17DD yellow fever (YF) vaccine (Fiocruz, Brazil). The vaccines were from the same batch (167VFC037Z). All of their infants were exclusively breast-fed. The women had not been vaccinated for YF previously.

Yellow fever vaccine is a live, attenuated virus preparation made from various strains of the 17D YF virus lineage. In Brazil, YF vaccine from the 17DD strain is produced by Bio-Manguinhos, a public sector vaccine manufacturer from the Oswaldo Cruz Foundation of the Brazilian Ministry of Health. YF vaccination is currently recommended in the entire Brazilian territory.

A YF outbreak was reaching Sao Paulo State in April 2017. The transmission area was close to the border with Minas Gerais State, in the Northeast of Sao Paulo State, more than $200 \mathrm{Km}$ from Angatuba. Despite being outside the transmission risk area at that time, YF vaccination is recommended in Angatuba since the 2009 YF outbreak in the Middle West of Sao Paulo State ${ }^{1}$.

The vaccination error was promptly reported to the health department of Angatuba and to the adverse event following immunization surveillance system. The Epidemiological Surveillance Center of Sao Paulo State (CVE) assisted the health department of Angatuba. The objectives were to avoid and to monitor the transmission of YF vaccine virus through breastfeeding and to investigate the presence of the virus in human milk. 


\section{MATERIALS AND METHODS}

The public health actions that were taken are: 1) Breastfeeding was immediately interrupted for 10 days and a special formula and appropriate baby bottle were made available to the mothers; 2) The babies who had breastfed after the mother had been vaccinated were followed by a pediatrician in a primary health care unit for 28 days for medical assistance if any sign or symptom appeared and a report of their health conditions was sent to the health department of Angatuba; 3) Serum and breastmilk were collected from the vaccinated mothers and sent to the Instituto Adolfo Lutz, an arbovirus reference laboratory in Sao Paulo State, Brazil, in order to test for the presence of genomic RNA of the vaccine virus strain and specific immunoglobulin $\mathrm{M}(\operatorname{IgM})$ antibodies.

The first serum and milk samples from all women were collected 8 days after vaccination (April 25), followed by collection 10 and 15 days after vaccination (April 27 and May 2, respectively). No infant serum was collected for YF virus testing.

Viral RNA was extracted from $140 \mu \mathrm{L}$ of serum using a QIAmp ${ }^{\circledR}$ viral RNA minikit (Qiagen, Hilden, Germany) and from $500 \mu \mathrm{L}$ of milk with a PureLink ${ }^{\circledR}$ Viral RNA/DNA minikit (Invitrogen, Thermo Fisher Scientific, Waltham, USA), according to the manufacturer's instructions. Viral genome was tested by real time reverse transcription polymerase chain reaction (RT-qPCR) protocol ${ }^{2}$. The Center for Diseases Control and Prevention (CDC/USA) protocol of MAC-ELISA was used for detecting IgM antibodies.
The present investigation was the official response to a public health crisis, thus not requiring an ethical council approval.

\section{RESULTS}

Table 1 shows the results of the tests performed. Viral RNA was not detected in any of the serum and breast milk samples tested. On day 8 after vaccination 10 women had a breastmilk sample tested and none had a positive RNA amplification test, resulting in a $0 \%$ detection rate with a $95 \%$ confidence interval (0 to 29,09). Only one of the 11 women had a positive result for specific YFV-IgM detection. No symptoms were reported among the infants.

\section{DISCUSSION}

Yellow fever virus, either the wild-type or the vaccinal one, have not been isolated from or detected in human breast milk ${ }^{3}$. However, there are previous reports of YF vaccine virus transmission through breastfeeding ${ }^{4-6}$. Both cases were infants who developed meningoencephalitis after their mothers had been vaccinated for YF during a postpartum visit. Yellow fever-specific IgM antibodies were present in the infant's serum and in the cerebrospinal fluid in the two cases ${ }^{4-6}$.

The World Health Organization (WHO) recommends that a risk-benefit assessment should be undertaken for all lactating women ${ }^{7}$. In areas where YF is endemic, or during outbreaks, the benefits of YF vaccination are likely to far

Table 1 - RT-qPCR results in human milk and serum samples and IgM results in serum samples of mothers inadvertently vaccinated for yellow fever, stratified by period (days) after vaccination. Angatuba, April 2017.

\begin{tabular}{|c|c|c|c|c|c|c|c|c|c|}
\hline \multirow{3}{*}{ Mothers } & \multicolumn{3}{|c|}{$8^{\text {th }}$ day } & \multicolumn{3}{|c|}{$10^{\text {th }}$ day } & \multicolumn{3}{|c|}{$15^{\text {th }}$ day } \\
\hline & \multirow{2}{*}{$\begin{array}{c}\text { Milk } \\
\text { RT-qPCR }\end{array}$} & \multicolumn{2}{|c|}{ Blood } & \multirow{2}{*}{$\begin{array}{c}\text { Milk } \\
\text { RT-Qpcr }\end{array}$} & \multicolumn{2}{|c|}{ Blood } & \multirow{2}{*}{$\begin{array}{c}\text { Milk } \\
\text { RT-qPCR }\end{array}$} & \multicolumn{2}{|c|}{ Blood } \\
\hline & & $\lg M$ & RT-qPCR & & IgM & RT-qPCR & & $\lg M$ & RT-qPCR \\
\hline 1 & $\mathrm{~N}$ & $\mathrm{~N}$ & $\mathrm{~N}$ & $\mathrm{~N}$ & $\mathrm{~N}$ & $\mathrm{~N}$ & $\mathrm{~N}$ & $\mathrm{~N}$ & $\mathrm{~N}$ \\
\hline 2 & $\mathrm{~N}$ & $\mathrm{~N}$ & $\mathrm{~N}$ & $\mathrm{~N}$ & $\mathrm{~N}$ & $\mathrm{~N}$ & - & $\mathrm{N}$ & $\mathrm{N}$ \\
\hline 3 & $\mathrm{~N}$ & $\mathrm{~N}$ & $\mathrm{~N}$ & $\mathrm{~N}$ & $\mathrm{~N}$ & $\mathrm{~N}$ & $\mathrm{~N}$ & $\mathrm{~N}$ & $\mathrm{~N}$ \\
\hline 4 & $\mathrm{~N}$ & $\mathrm{~N}$ & $\mathrm{~N}$ & $\mathrm{~N}$ & $\mathrm{~N}$ & $\mathrm{~N}$ & $\mathrm{~N}$ & $\mathrm{~N}$ & $\mathrm{~N}$ \\
\hline 5 & $\mathrm{~N}$ & $\mathrm{~N}$ & $\mathrm{~N}$ & $\mathrm{~N}$ & $\mathrm{~N}$ & $\mathrm{~N}$ & $\mathrm{~N}$ & $\mathrm{~N}$ & $\mathrm{~N}$ \\
\hline 6 & $\mathrm{~N}$ & $\mathrm{~N}$ & $\mathrm{~N}$ & $\mathrm{~N}$ & $\mathrm{~N}$ & $\mathrm{~N}$ & $\mathrm{~N}$ & $\mathrm{~N}$ & $\mathrm{~N}$ \\
\hline 7 & $\mathrm{~N}$ & $\mathrm{~N}$ & $\mathrm{~N}$ & $\mathrm{~N}$ & $\mathrm{~N}$ & $\mathrm{~N}$ & $\mathrm{~N}$ & $\mathrm{~N}$ & $\mathrm{~N}$ \\
\hline 8 & $\mathrm{~N}$ & $\mathrm{~N}$ & $\mathrm{~N}$ & $\mathrm{~N}$ & $\mathrm{~N}$ & $\mathrm{~N}$ & $\mathrm{~N}$ & $\mathrm{~N}$ & $\mathrm{~N}$ \\
\hline 9 & $\mathrm{~N}$ & $\mathrm{~N}$ & $\mathrm{~N}$ & $\mathrm{~N}$ & $\mathrm{~N}$ & $\mathrm{~N}$ & $\mathrm{~N}$ & $\mathrm{~N}$ & $\mathrm{~N}$ \\
\hline 10 & ND & $N$ & ND & $\mathrm{N}$ & $\mathrm{N}$ & $N$ & ND & $\mathrm{N}$ & $\mathrm{N}$ \\
\hline 11 & $\mathrm{~N}$ & $\mathbf{P}$ & $\mathrm{N}$ & ND & ND & ND & ND & ND & ND \\
\hline
\end{tabular}

$\mathrm{N}=$ negative $; \mathrm{P}=$ positive $; \mathrm{ND}=$ not done. 
outweigh the risks of a potential transmission of the vaccine virus to the infant. Vaccination is also recommended, if indicated, to pregnant or breastfeeding women travelling to endemic areas when the travel cannot be avoided or postponed ${ }^{7}$. According to the Brazilian Ministry of Health $(\mathrm{MoH})$, the vaccination of mothers breastfeeding children under the age of 6 months should be avoided or postponed until the child reaches 6 months of age ${ }^{6}$. If it is not possible to postpone the vaccination, the mother can store breast milk before the vaccination, to be offered to the infant during the period in which breastfeeding will be interrupted ${ }^{8}$.

Before 2016, the $\mathrm{MoH}$ recommended 15 days of breastfeeding interruption after YF vaccination ${ }^{8}$. During the 2016 - 2019 YF outbreak, the recommendation changed to 10 days of breastfeeding interruption ${ }^{9}$. In this study the 17DD virus was not detected in human milk eight days after YF vaccination in 11 women and none of the infants developed any symptoms.

This study has some clear limitations, the small sample size does not allow us to rule out the occurrence of rare adverse events. It is also theoretically possible that, if the virus was present in the breast milk in very low quantities, the RNA amplification test could come out negative and transmission could still occur. No samples were collected from the infants, which could have helped to rule out an asymptomatic transmission of the yellow fever vaccine virus. Nonetheless, the fact that no adverse effects were reported in infants is reassuring.

Studies based on surveillance data showed that the wrong vaccine administered is the most commonly reported vaccination error ${ }^{10,11}$. The vaccination error in Angatuba was classified as an accidental and isolated event. YF vaccine and MMR vaccine have multiple dose presentation and they have the same producer (Bio-Manguinhos), which could facilitate the confusion. However, the color of the bottle cap and the label are different. The current high number of different vaccines available in the Brazilian immunization schedule in Brazil demands well prepared health professionals. Vaccination errors are serious events because they may harm patients and also cause a negative impact on the population's confidence on vaccination, resulting in reduction of the immunization coverage ${ }^{10}$.

Despite these limitations, our results strengthens the eeffectiveness of the Brazilian $\mathrm{MoH}$ recommendations to interrupt breastfeeding for 10 days after vaccination. It should also be considered that strategies to minimize breastfeeding interruptions are desirable considering its importance for the infants' development ${ }^{12,13}$. Further studies are required to rule out the occurrence of rare adverse events in this population.

\section{ACKNOWLEDGMENTS}

The authors would like to thank all the collaborators from the Health Department of Angatuba.

\section{AUTHORS' CONTRIBUTIONS}

EGF, VBGP and HKS conducted the investigation together with the technicians of the municipality of Angatuba; JSN performed the laboratory assay; EGF drafted the initial manuscript. VBGP, HKS and JSN reviewed the manuscript. All authors approved the final manuscript as submitted.

\section{CONFLICT OF INTERESTS}

None.

\section{FUNDING}

None.

\section{REFERENCES}

1. São Paulo. Secretaria de Estado da Saúde. Coordenadoria de Controle de Doenças. Centro de Vigilância Epidemiológica "Alexandre Vranjac". Febre amarela silvestre, Estado de São Paulo, 2009: boletim final, dezembro de 2009. [cited 2020 Apr 23]. Available from: http://www.saude.sp.gov.br/resources/ cve-centro-de-vigilancia-epidemiologica/areas-de-vigilancia/ doencas-de-transmissao-por-vetores-e-zoonoses/doc/famarela/ boletim_fasp171209.pdf

2. Domingo C, Patel P, Yillah J, Weidmann M, Méndez JA, Nakouné ER, et al. Advanced yellow fever virus genome detection in point-of-care facilities and reference laboratories. J Clin Microbiol. 2012;50:4054-60.

3. Mann TZ, Haddad LB, Williams TR, Hills SL, Read JS, Dee DL, et al. Breast milk transmission of flaviviruses in the context of Zika virus: a systematic review. Paediatr Perinat Epidemiol. 2018;32:358-68.

4. Centers for Disease Control and Prevention. Transmission of yellow fever vaccine virus through breast-feeding: Brazil: 2009. MMWR Morb Mortal Wkly Rep. 2010;59:130-2.

5. Traiber C, Coelho-Amaral P, Ritter VR, Winge A. Infant meningoencephalitis caused by yellow fever vaccine virus transmitted via breastmilk. J Pediatr (Rio J). 2011;87:269-72.

6. Kuhn S, Twele-Montecinos L, MacDonald J, Webster P, Law B. Case report: probable transmission of vaccine strain of yellow fever virus to an infant via breast milk. CMAJ. 2011;183:E2435. 
7. World Health Organization. Vaccines and vaccination against yellow fever. WHO position paper - June 2013.Wkly Epidemiol Rec. 2013;88:269-83.

8. Brasil. Ministério da Saúde. Secretaria de Vigilância em Saúde. Departamento de Vigilância das Doenças Transmissíveis. Manual de vigilância epidemiológica de eventos adversos pósvacinação. $3^{a}$ ed. Brasília: Ministério da Saúde; 2014. [cited 2020 Apr 23]. Available from: http://bvsms.saude.gov.br/bvs/ publicacoes/manual_vigilancia_epidemiologica_eventos_ adversos_pos_vacinacao.pdf

9. Brasil. Ministério da Saúde. Secretaria de Vigilância em Saúde. Coordenação-Geral de Desenvolvimento da Epidemiologia em Serviços. Guia de vigilância em saúde : volume único. $3^{\mathrm{a}}$ ed. Brasília: Ministério da Saúde; 2019. [cited 2020 Apr 23]. Available from: http://bvsms.saude.gov.br/bvs/publicacoes/ guia_vigilancia_saude_3ed.pdf
10. Morse-Brady J, Marie Hart A. Prevalence and types of vaccination errors from 2009 to 2018: a systematic review of the medical literature. Vaccine. 2020;38:1623-9.

11. Braga PC, Silva AE, Mochizuki LB, Lima JC, Sousa MR, Bezerra AL. Incidence of post-vaccination adverse events in children. J Nurs UFPE Online. 2017;11 Suppl 10:4126-35.

12. Ip S, Chung M, Raman G, Chew P, Magula N, DeVine D, et al. Breastfeeding and maternal and infant health outcomes in developed countries. Evid Rep Technol Assess (Full Rep). 2007;1-186.

13. Section on Breastfeeding. Breastfeeding and the use of human milk. Pediatrics. 2012;129:e827-41. 